\title{
Effects of different drip irrigation regimes on saline-sodic soil nutrients and cotton yield in an arid region of Northwest China
}

\author{
Ruoshui Wang ${ }^{\mathrm{a}, *}$, Yaohu Kang ${ }^{\mathrm{b}}$, Shuqin Wan ${ }^{\mathrm{b}}$ \\ a Key Laboratory of Soil and Water Conservation and Desertification Combating, Ministry of Education, College of Soil and Water Conservation, \\ Beijing Forestry University, Beijing 100083, China \\ ${ }^{\mathrm{b}}$ Key Laboratory of Water Cycle and Related Land Surface Processes, Institute of Geographic Science and Natural Resources Research, \\ Chinese Academy of Sciences, 11 A Datun Road, Anwai, Beijing 100101, China
}

\section{A R T I C L E I N F O}

\section{Article history:}

Received 14 August 2014

Accepted 31 January 2015

Available online 19 February 2015

\section{Keywords:}

Soil nitrogen

Soil salinity

SAR

Soil C:N ratio

Nutrient distribution

\begin{abstract}
A B S T R A C T
A field experiment was conducted on a saline wasteland in Xinjiang, Northwest China, during 2008-2010 to evaluate the nutrient behavior and cotton yield during reclamation, applied by different drip irrigation regimes. The experiment included five treatments in which the soil matric potential (SMP) thresholds at $20 \mathrm{~cm}$ depth were controlled at $-5,-10,-15,-20$ and $-25 \mathrm{kPa}$. The results indicated that both soil salinity and sodicity declined significantly at $0-40 \mathrm{~cm}$ depth and greater reductions were achieved at higher SMP thresholds $(-5$ and $-10 \mathrm{kPa})$ than in other treatments. The distributions in soil inorganic nitrogen $(\mathrm{N})$ and available phosphorus $(\mathrm{P})$ and potassium $(\mathrm{K})$ in the soil profile were mainly influenced by the point-source characteristic of drip irrigation, drip irrigation regime and fertilization mode. With the reclamation of both soil chemical and physical properties, there were dramatic increases in soil N, P and $\mathrm{K}$ concentration by the end of 2010 . The soil nutrient concentrations in $\mathrm{N}, \mathrm{P}$ and $\mathrm{K}$ were all proportional to the SMP thresholds, as higher SMP could result in greater reductions in soil salinity and sodicity. Since crop growth became more vigorous during reclamation, there was also a considerable increase (9.7-31.9\%) in soil organic carbon by the end of 2010 , and the concentrations were also proportional to SMP thresholds. The highest cotton yield was obtained in S1 $(-5 \mathrm{kPa})$ treatment for both $2009\left(2.87 \mathrm{Mg} \mathrm{ha}^{-1}\right)$ and 2010 (3.60 $\mathrm{Mg} \mathrm{ha}^{-1}$ ). Additionally, the soil C: $\mathrm{N}$ ratios were inversely proportional to the SMP thresholds in 2009 and 2010. Considering the soil reclamation efficiency, soil nutrient stocks and cotton yield, SMP thresholds of -5 and $-10 \mathrm{kPa}$ could be used as effective measures to trigger irrigation in the first 3 years of saline-sodic soil reclamation in Xinjiang, Northwest China.
\end{abstract}

(c) 2015 Elsevier B.V. All rights reserved.

\section{Introduction}

Soil salinity and sodicity, and their combination, are worldwide problems posing significant threats to the sustainable development of agriculture, especially in arid and semiarid regions (Oster et al., 1996; Qadir et al., 1997; Ma et al., 2012). In Xinjiang, a typical arid region of Northwest China, there are approximately $1.1 \times 10^{7}$ ha of saline wasteland, of which $7.27 \times 10^{6}$ ha are overly saline-sodic soils (Xi et al., 2005). Salinization and sodification of soils are serious land degradation issues in Xinjiang, where it is estimated that onethird of the arable land is affected by salinity and sodicity, which greatly reduces agricultural output in the area (Chen et al., 2010).

Under saline conditions, the reduced growth of crops is mainly attributed to the osmotic effect, which can reduce soil water

\footnotetext{
* Corresponding author.

E-mail address: wrsily_2002@163.com (R. Wang).
}

potential and nutrient availability and uptake by plants (Al-Karaki, 1997; Elgharably, 2011). Sodicity increases clay dispersion and reduces aggregate stability, which results in declining air permeability, infiltration and hydraulic conductivity (Wong et al., 2010). This can seriously hinder root respiration, hence reducing plant growth and activity of soil organisms. However, the typical inland arid conditions and water resource shortages in Xinjiang increase the difficulty of reclaiming saline-sodic soil.

Drip irrigation with its characteristic of applying water at low discharge rate and high frequency over a long period of time can maintain constant and high soil water potential in the root zone and reduce salinity levels in soil water by leaching, particularly near the drip emitters (Keller and Bliesner, 1990; Wang et al., 2011). Among all the factors, drip irrigation scheduling is the most important in salt leaching efficiency. Previous studies have evaluated the impact of different levels of soil matric potential (SMP) to trigger drip irrigation in arid and semiarid regions (Dou et al., 2011; Sun et al., 2012; Wan et al., 2012; Wang et al., 2012). These studies have 
mainly focussed on soil salinity, sodicity and soil hydraulic properties, particularly with regard to soil salt movement and plant health. However, very few studies have explored soil nutrients during the reclamation process under drip irrigation, and hence understanding of nutrients in saline-sodic soil under drip irrigation is limited.

Soil structure and root activity decline with increasing sodicity in a saline-sodic soil, thus reducing nutrient mobilities and leading to nutrient deficiencies (Wong et al., 2010). Therefore, organic matter and mineral nutrients in saline-sodic soils are generally at low levels. Nutrient behavior in saline-sodic soils during the reclamation process needs to be evaluated because of the changes in soil chemical composition during and after reclamation. Especially under conditions of drip irrigation with mineral fertilizer input, the variations of soil nutrients during reclamation remain largely unknown.

The objectives of this study were (1) to investigate the effects of drip irrigation triggered by different SMP thresholds on distribution of soil mineral nutrients (inorganic N, available P and K); (2) to ascertain variation in soil organic carbon (SOC) and (3) to measure the effects of different SMP thresholds on soil carbon-to-nitrogen $(\mathrm{C}: \mathrm{N})$ ratio and seed cotton yield during 3 years of reclamation under drip irrigation.

\section{Materials and methods}

\subsection{Experimental site}

The field experiments were conducted during 2008-2010 on a saline wasteland at Karamay farm (latitude: $45^{\circ} 22^{\prime} \mathrm{N}$ and longitude: $84^{\circ} 50^{\prime} \mathrm{E}, 350 \mathrm{~m}$ a.s.l.), which is located in the middle of the Jungger Basin in the Xinjiang Province, Northwest China. The area has a typical inland arid climate with annual precipitation of about $105 \mathrm{~mm}$, mainly concentrated in June-August, and average annual evaporation capacity and temperature of about $3545 \mathrm{~mm}$ and $8.0^{\circ} \mathrm{C}$, respectively (Wang et al., 2007). The average depth to groundwater is about $2.5-3.0 \mathrm{~m}$, and the electrical conductivity of the groundwater $\left(\mathrm{EC}_{\mathrm{gw}}\right)$ ranged between 30 and $52 \mathrm{dS} \mathrm{m}^{-1}$. Irrigation water is pumped from the reservoir in the west suburbs of Karamay, with $\mathrm{EC}_{\mathrm{iw}}$ of $0.3 \mathrm{dS} \mathrm{m}^{-1}$. The soils in the area are chloride-sulfatetype saline-sodic soils, which are typically in Xinjiang (Wang et al., 1993; Xi et al., 2005). The climate and special geographical conditions make this region liable to accumulate salt on the soil surface. The $\mathrm{EC}_{\mathrm{e}}$ (electrical conductivity of saturated paste) and the nutrient concentration of soil samples at different soil depths are reported in Tables 1 and 2.

\subsection{Plot layout and irrigation water management}

The experiment included five water treatments (S1-S5) based on the SMP, measured with tensiometers located at a depth of $20 \mathrm{~cm}$ beneath a dripper near the center of the plot for each treatment (Fig. 1), that determined when to irrigate or to trigger irrigation. The SMP thresholds that triggered irrigation were -5 (S1), -10 (S2), -15 (S3), -20 (S4) and $-25 \mathrm{kPa}$ (S5). These treatments were replicated three times in a completely randomized block design. Plots consisted of 20 rows of cotton planted on 10 raised $(15 \mathrm{~cm})$ beds during 2008-2010, spaced at $0.8 \mathrm{~m}$. The beds were mulched with white polyethylene sheets after sowing. Each bed was $0.4 \mathrm{~m}$ wide and $3.8 \mathrm{~m}$ long (Fig. 1). The size of plots was $8.0 \mathrm{~m} \times 3.8 \mathrm{~m}$. The location of water treatments was the same during the 3 years of the experiments.

Each treatment was irrigated with an independent irrigation system. The system consisted of a water tank (1000 L) and 30 drip tubes (10 tubes per plot). A tank filled with irrigation water was placed at $1 \mathrm{~m}$ above the ground to maintain water pressure in the

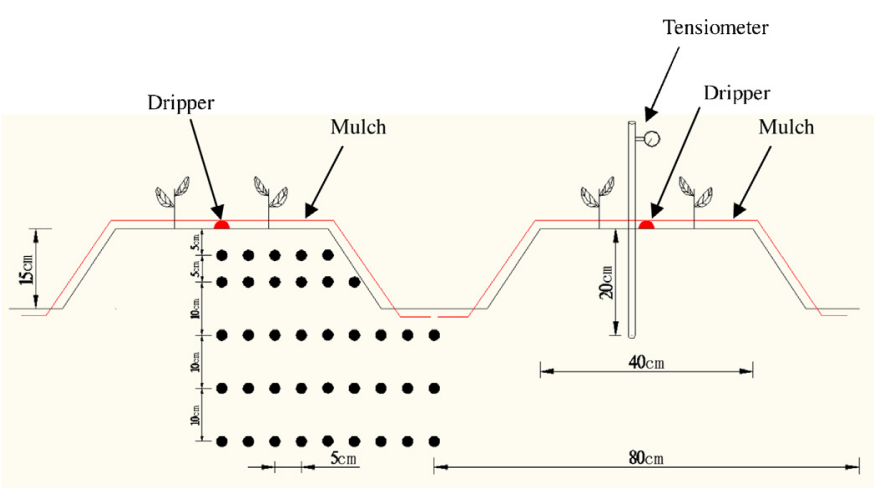

Fig. 1. Dimensions of beds and position of the tensiometer and soil sampling.

irrigation system within the range of $10-20 \mathrm{kPa}$. The drip tubes with $20 \mathrm{~cm}$ emitter intervals were placed at the center of each raised bed. To enable seedlings to emerge, $40 \mathrm{~mm}$ of water was applied to all treatments immediately after seeding. Cotton seedlings were thinned to the spacing described below, and irrigation treatments were initiated on 15 June (16 days after seeding), 2 June ( 23 days after seeding) and 5 June (26 days after seeding) in 2008, 2009 and 2010 , respectively. Thereafter, $9.8 \mathrm{~mm}$ of water was applied when SMP reached the target values. The tensiometers were observed three times daily: 8:00, 12:00 and 18:00 h.

\subsection{Plant and fertilizer management}

Seeds of cotton were sown on 30 May 2008, 10 May 2009 and 8 May 2010 in double rows. The rows were $30 \mathrm{~cm}$ apart; within a row, the seeds were sown $10 \mathrm{~cm}$ apart. Soon after emergence, the plants were thinned to a spacing of $30 \mathrm{~cm}$. Since the seeding date was relatively late in 2008, the emergence rate was low and the bolls did not grow well enough for harvest due to the low temperature in the late growing stages. Accordingly, there were no yield data for 2008. In 2009 and 2010, harvest was started on 2 October and 30 September and finished on 20 and 25 November, and the total harvest period lasted 49 and 57 days, respectively. The seed cotton was picked by hand at 4-7-day intervals, and the total weight per plot was checked at each harvest time.

Basal dose of $450 \mathrm{~kg} \mathrm{ha}^{-1}$ of a compound fertilizer (16\% N, 35\% $\mathrm{P}_{2} \mathrm{O}_{5}$ and $8 \% \mathrm{~K}_{2} \mathrm{O}$ ) was uniformly applied to the plots at the time of plowing before seeding in 2008-2010. This fertilizer dose was supplemented with urea $(46 \% \mathrm{~N})$, applied with the irrigation water; $0.15 \mathrm{~L}$ of an $11 \mathrm{mg} \mathrm{kg}^{-1}$ urea solution was added to the irrigation tank every time irrigation was applied.

\subsection{Soil sampling and chemistry analyses}

In a saline soil, the soil salinity distributions clearly showed leaching near the drip lines, an area where the root density has been found to be maximum (Hanson et al., 2006; Hu et al., 2009). Since the low $\mathrm{EC}_{\mathrm{e}}$ zones we found were usually within $40 \mathrm{~cm}$ (Wang et al., 2011), a soil depth interval of $0-40 \mathrm{~cm}$ was analyzed. Soil samples were obtained on soil cores from each plot with an auger $(2.0 \mathrm{~cm}$ in diameter and $15 \mathrm{~cm}$ long) on 12 May 2008 (before seeding), 13 September 2008, 14 September 2009 and 13 September 2010 (after irrigation ended). The distances of sampling points to drip emitters were $0,5,10,15,20,25,30,35$ and $40 \mathrm{~cm}$, and all sample depths were the same: $0-5,5-10,10-20,20-30$ and $30-40 \mathrm{~cm}$ (Fig. 1). All soil samples were air-dried and sieved through a $1 \mathrm{~mm}$ sieve.

The soluble salt estimates were based on extracts of saturated soil. The EC values were determined with a conductivity meter (DDS-11A, REX, Shanghai). Sodium adsorption ratio (SAR) was 
Table 1

Soil texture, bulk density, electrical conductivity of saturated paste extracts $\left(\mathrm{EC}_{\mathrm{e}}\right)$ and SAR of the initial soil profile at Karamay, Xinjiang, Northwest China.

\begin{tabular}{|c|c|c|c|c|c|c|c|}
\hline \multirow[t]{2}{*}{ Soil depth (cm) } & \multicolumn{3}{|c|}{ Soil mechanical composition (\%) } & \multirow[t]{2}{*}{ Soil texture } & \multirow[t]{2}{*}{ Soil bulk density $\left(\mathrm{g} \mathrm{cm}^{-3}\right)$} & \multirow[t]{2}{*}{$\mathrm{EC}_{\mathrm{e}}\left(\mathrm{dS} \mathrm{m}^{-1}\right)$} & \multirow[t]{2}{*}{ SAR } \\
\hline & Clay & Silt & Sand & & & & \\
\hline $0-40$ & 1.18 & 93.5 & 5.34 & Silt & 1.33 & 46.1 & 40.3 \\
\hline $40-60$ & 1.03 & 99.0 & 0.00 & Silt & 1.43 & 27.4 & 25.7 \\
\hline $60-90$ & 0.54 & 95.4 & 4.07 & Silt & 1.47 & 15.4 & 28.2 \\
\hline $90-120$ & 0.41 & 96.0 & 3.56 & Silt & 1.56 & 30.4 & 19.5 \\
\hline $120-180$ & 0.26 & 96.1 & 3.68 & Silt & 1.38 & 16.4 & 21.4 \\
\hline
\end{tabular}

Table 2

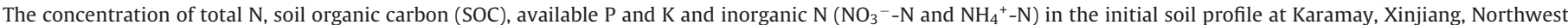
China.

\begin{tabular}{|c|c|c|c|c|c|c|}
\hline Soil depth $(\mathrm{cm})$ & Total N (\%) & SOC (\%) & Available $\mathrm{P}\left(\mathrm{mg} \mathrm{kg}^{-1}\right)$ & Available $\mathrm{K}\left(\mathrm{mg} \mathrm{kg}^{-1}\right)$ & $\mathrm{NO}_{3}{ }^{-} \mathrm{N}\left(\mathrm{mg} \mathrm{kg}^{-1}\right)$ & $\mathrm{NH}_{4}{ }^{+}-\mathrm{N}\left(\mathrm{mg} \mathrm{kg}^{-1}\right)$ \\
\hline $0-30$ & 0.03 & 0.33 & 4.06 & 115.4 & 8.4 & 18.7 \\
\hline $30-60$ & 0.02 & 0.27 & 2.44 & 119.5 & 10.6 & 9.9 \\
\hline $60-90$ & 0.02 & 0.26 & 1.83 & 132.0 & 10.3 & 10.8 \\
\hline $90-120$ & 0.01 & 0.21 & 2.23 & 82.4 & 11.1 & 9.9 \\
\hline $120-180$ & 0.02 & 0.14 & 0.81 & 70.1 & 11.5 & 9.0 \\
\hline
\end{tabular}

calculated from the following equation using concentrations of the cations $\mathrm{Na}^{+}, \mathrm{Ca}^{2+}$ and $\mathrm{Mg}^{2+}$ in $\mathrm{mmol}_{\mathrm{C}} \mathrm{L}^{-1}$ :

$\mathrm{SAR}=\frac{\mathrm{CNa}}{\left[\left(\mathrm{C}_{\mathrm{Ca}}+\mathrm{C}_{\mathrm{Mg}}\right) / 2\right]^{1 / 2}}$

Concentrations of $\mathrm{Na}^{+}$were determined by flame photometer method and those of $\mathrm{Ca}^{2+}$ and $\mathrm{Mg}^{2+}$ by EDTA titration method (Bao, 2005).

Total nitrogen (TN) was determined using the micro-Kjeldahl method, with $2.0 \mathrm{~g}$ of soil being digested in $\mathrm{H}_{2} \mathrm{SO}_{4}$ and $\mathrm{H}_{2} \mathrm{O}_{2}$ solution before measurement (Stuart, 1936). The inorganic $\mathrm{N}$ (ammonium and nitrate: $\mathrm{NH}_{4}{ }^{+}$and $\mathrm{NO}_{3}{ }^{-}$) was determined in $2 \mathrm{~mol} \mathrm{~L}^{-1} \mathrm{KCl}$ extract on a Skalar automatic analyzer (Bundy and Meisinger, 1994). Olsen P (available P) was extracted with $0.5 \mathrm{~mol} \mathrm{~L}^{-1} \mathrm{NaHCO}_{3}$ at $\mathrm{pH} 8.5$ and determined according to Olsen and Sommers (1982). Available potassium (K) was determined by flame photometer method using $1.0 \mathrm{~mol} \mathrm{~L}^{-1} \mathrm{CH}_{3} \mathrm{COONH}_{4}$ adjusted to $\mathrm{pH} 7.0$ as the extractant. Soil organic carbon (SOC) was determined by high temperature combustion on a LECO CNS-2000 analyzer (Wong et al., 2008).

The values for soil organic carbon (SOC) and total nitrogen (TN) were used to calculate the carbon-to-nitrogen ratio, C:N.

\subsection{Statistical analyses}

Tukey's significant difference (TSD) was used to compare and rank the treatment means at $p<0.05$ for the $\mathrm{EC}_{\mathrm{e}}, \mathrm{SAR}, \mathrm{TN}, \mathrm{C}: \mathrm{N}$ ratio and cotton yield. Two factors, sampling date $(n=6)$ and treatment $(n=5)$, were included in the ANOVA for soil EC $\mathrm{e}$, SAR and nutrients. Statistical analyses were performed using SPSS (version 15.0) and Excel. Soil nutrient spatial distributions were mapped with Surfer 7.0.

\section{Results and discussion}

\subsection{Weather and irrigation}

The summer temperatures (July and August) in 2008 were higher than those in 2009 and 2010, while in other months, the mean temperatures were very similar among the 3 years (Fig. 2). Total rainfall during the experimental period was 70.8, 81.2 and $114.6 \mathrm{~mm}$ in 2008, 2009 and 2010, respectively, with correspondingly seven, six and nine effective rainfall $(>5 \mathrm{~mm}$ ) events. There were four heavy rainfall events (rainfall intensity $>16 \mathrm{~mm} \mathrm{~h}^{-1}$ ) in early July 2008, which was twice as much as observed in 2009 and
2010. Comparatively, the temporal distribution of rainfall was more uniform in 2010 than in the other years (Fig. 2).

Before cotton emerged, all treatment plots were irrigated with the same amount of water to ensure uniform germination. After that, irrigations were triggered by different SMP thresholds. Higher SMP threshold resulted in more irrigation times and hence greater amounts of irrigation water (Table 3). The most irrigation water was applied in $\mathrm{S} 1(-5 \mathrm{kPa})$ each year, while the maximum $(665.6 \mathrm{~mm})$ was in 2008.

\subsection{Temporal changes of soil $E C_{e}$ and $S A R$}

The variation of soil $\mathrm{EC}_{\mathrm{e}}$ and $\mathrm{SAR}$ after irrigation terminated in each year is shown in Fig. 3. During the irrigation season, salts moved downward with water, thus after the irrigation ceased in fall (September), the $\mathrm{EC}_{\mathrm{e}}$ value significantly declined for each treatment compared with the initial values in 2008 before seeding ( 13 May) (Fig. 3a). Compared with the initial $\mathrm{EC}_{\mathrm{e}}$ in 2008, the reduction in $\mathrm{EC}_{\mathrm{e}}$ after 3 years at $0-40 \mathrm{~cm}$ depth varied from $56 \%$ (S5) to $89 \%$ (S1) for the five treatments. The reduction of $\mathrm{EC}_{\mathrm{e}}$ decreased with the decreasing SMP threshold for each year. Thus more reclamation occurred in S1 $(-5 \mathrm{kPa})$ and S2 $(-10 \mathrm{kPa})$ than for the other treatments. By the end of the third cropping season, the $\mathrm{EC}_{\mathrm{e}}$ for $\mathrm{S} 1$ and S2 treatments had reduced from 47.0 to 5.3 and $8.1 \mathrm{dS} \mathrm{m}^{-1}$, respectively, which are in the range of threshold salinity of $7.7 \mathrm{dS} \mathrm{m}^{-1}$ for cotton (Maas and Hoffman, 1977). This could only occur if more

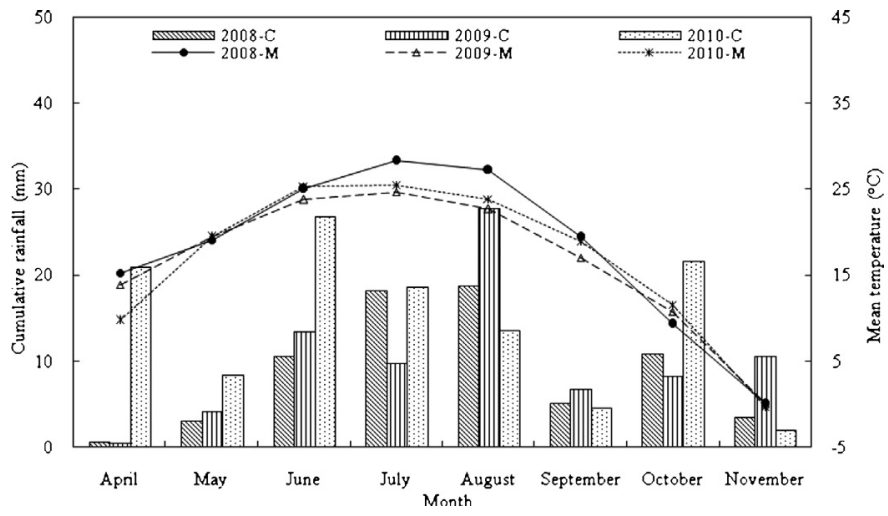

Fig. 2. The monthly rainfall and mean temperature during experimental stages in each year. 2008-C, 2009-C and 2010-C, monthly cumulative rainfall in 2008, 2009 and 2010, respectively; 2008-M, 2009-M and 2010-M, monthly mean temperature in 2008, 2009 and 2010, respectively. 
Table 3

Irrigation and amount of applied water for each treatment during the experimental stages in 2008, 2009 and 2010.

\begin{tabular}{|c|c|c|c|c|}
\hline \multirow[t]{2}{*}{ Years } & \multirow[t]{2}{*}{ Treatments } & \multirow[t]{2}{*}{ Fresh water for seedlings (mm) } & \multicolumn{2}{|l|}{ During treatment } \\
\hline & & & Irrigation times & Water depth (mm) \\
\hline \multirow[t]{5}{*}{2008} & $\mathrm{~S} 1(-5 \mathrm{kPa})$ & 40 & 68 & 666 \\
\hline & $\mathrm{S} 2(-10 \mathrm{kPa})$ & 40 & 47 & 460 \\
\hline & $\mathrm{S} 3(-15 \mathrm{kPa})$ & 40 & 30 & 293 \\
\hline & $\mathrm{S} 4(-20 \mathrm{kPa})$ & 40 & 28 & 274 \\
\hline & $\mathrm{S} 5(-25 \mathrm{kPa})$ & 40 & 26 & 254 \\
\hline \multirow[t]{5}{*}{2009} & $\mathrm{~S} 1(-5 \mathrm{kPa})$ & 40 & 65 & 636 \\
\hline & $\mathrm{S} 2(-10 \mathrm{kPa})$ & 40 & 47 & 460 \\
\hline & $\mathrm{S} 3(-15 \mathrm{kPa})$ & 40 & 38 & 372 \\
\hline & $\mathrm{S} 4(-20 \mathrm{kPa})$ & 40 & 37 & 362 \\
\hline & $\mathrm{S} 5(-25 \mathrm{kPa})$ & 40 & 25 & 244 \\
\hline \multirow[t]{5}{*}{2010} & $\mathrm{~S} 1(-5 \mathrm{kPa})$ & 40 & 65 & 627 \\
\hline & $\mathrm{S} 2(-10 \mathrm{kPa})$ & 40 & 56 & 541 \\
\hline & $\mathrm{S} 3(-15 \mathrm{kPa})$ & 40 & 38 & 363 \\
\hline & $\mathrm{S} 4(-20 \mathrm{kPa})$ & 40 & 28 & 274 \\
\hline & $\mathrm{S} 5(-25 \mathrm{kPa})$ & 40 & 24 & 235 \\
\hline
\end{tabular}

water was applied to the soil than was used by the crop within this depth, thus causing leaching.

The changes in SAR with time (Fig. 3b) were similar to those of $\mathrm{EC}_{\mathrm{e}}$. There were considerable reductions of SAR at 0-40 cm depth. After the third irrigation season, the declines in SAR, relative to the initial level, were $76,60,52,46$ and $41 \%$ for S1-S5 treatments, respectively (Fig. $3 \mathrm{~b}$ ). In the fall, the reduction of SAR at $0-40 \mathrm{~cm}$ soil depth also decreased with the decreasing SMP threshold. The reductions in SAR could be enhanced in calcareous soil under cropped conditions, because plant roots can affect the soil chemical environment by increasing the partial pressure of carbon dioxide $\left(\mathrm{CO}_{2}\right)$, which will facilitate the dissolution of calcite, thereby providing a source of $\mathrm{Ca}$ to replace exchangeable $\mathrm{Na}$ (Qadir et al., 2002). This process is more efficient in cropped than in uncropped soils as plant roots can exert higher $\mathrm{CO}_{2}$ partial pressure (Robbins, 1986a,b; Qadir et al., 2002, 2007). Apart from root action, the decrease in SAR can also be attributed to $\mathrm{Ca}^{2+}$ supplied in irrigation water and lime dissolution through soil microbial activity (Qadir et al., 1997).

\subsection{Spatial and temporal changes in soil nutrients}

\subsubsection{Soil $N$}

In this study, soil inorganic $\mathrm{N}\left(\mathrm{NO}_{3}{ }^{-}-\mathrm{N}\right.$ and $\left.\mathrm{NH}_{4}{ }^{+}-\mathrm{N}\right)$ distribution within $40 \mathrm{~cm}$ depth was analyzed after irrigation ceased for each treatment in 2010. The two types of inorganic $\mathrm{N}$ accumulated mainly in the upper soil layer $(0-20 \mathrm{~cm})$ (Fig. 4). The $\mathrm{NO}_{3}{ }^{-}-\mathrm{N}$ and
$\mathrm{NH}_{4}{ }^{+}-\mathrm{N}$ formed a concentration gradient with soil depth, with the highest values concentrated around the drip emitter. This may be due to the point-source characteristic of drip irrigation and the fertilization mode. Under point-source infiltration, water can form a wetting area in close proximity to a dripper (Chen et al., 2009); hence, the nutrient dissolved in and moving with irrigation water can form a similar shape to the wetting area in the soil profile. Compared with the initial value (Table 2), there were dramatic rises in both the $\mathrm{NO}_{3}{ }^{-}-\mathrm{N}$ and $\mathrm{NH}_{4}{ }^{+}-\mathrm{N}$ in the soil profile for each treatment after 3 years of the experiment. There are two main reasons for this: applied fertilizer and crop roots. Applying $\mathrm{N}$ fertilizer, on the whole, can increase the inorganic $\mathrm{N}$ concentration and therefore the $\mathrm{NO}_{3}{ }^{-}-\mathrm{N}$ and $\mathrm{NH}_{4}{ }^{+}-\mathrm{N}$ stocks in the soil profile (Yin et al., 2007). Additionally, soil reclamation was more efficient at higher SMP thresholds (Fig. 3), and thus more roots distributed in soil for $\mathrm{S} 1(-5 \mathrm{kPa})$ and S2 $(-10 \mathrm{kPa})$ treatments could promote adsorption, transportation and biometabolic action of ionic species in soil, which results in accumulation of nutrients (Ma et al., 2012). This can also explain why more $\mathrm{NO}_{3}{ }^{-}-\mathrm{N}$ and $\mathrm{NH}_{4}{ }^{-}-\mathrm{N}$ accumulated at higher SMP thresholds after the experiment ended in 2010 (Fig. 4).

After the first growing season, there was a significant increase in total $\mathrm{N}$ in the upper $40 \mathrm{~cm}$ of soil in all treatments, compared with those before seeding (Fig. 5); the increase rates in the range of 8.4-38.9\% were proportional to the SMP thresholds. In the following 2 years, the total $\mathrm{N}$ for each treatment steadily increased.
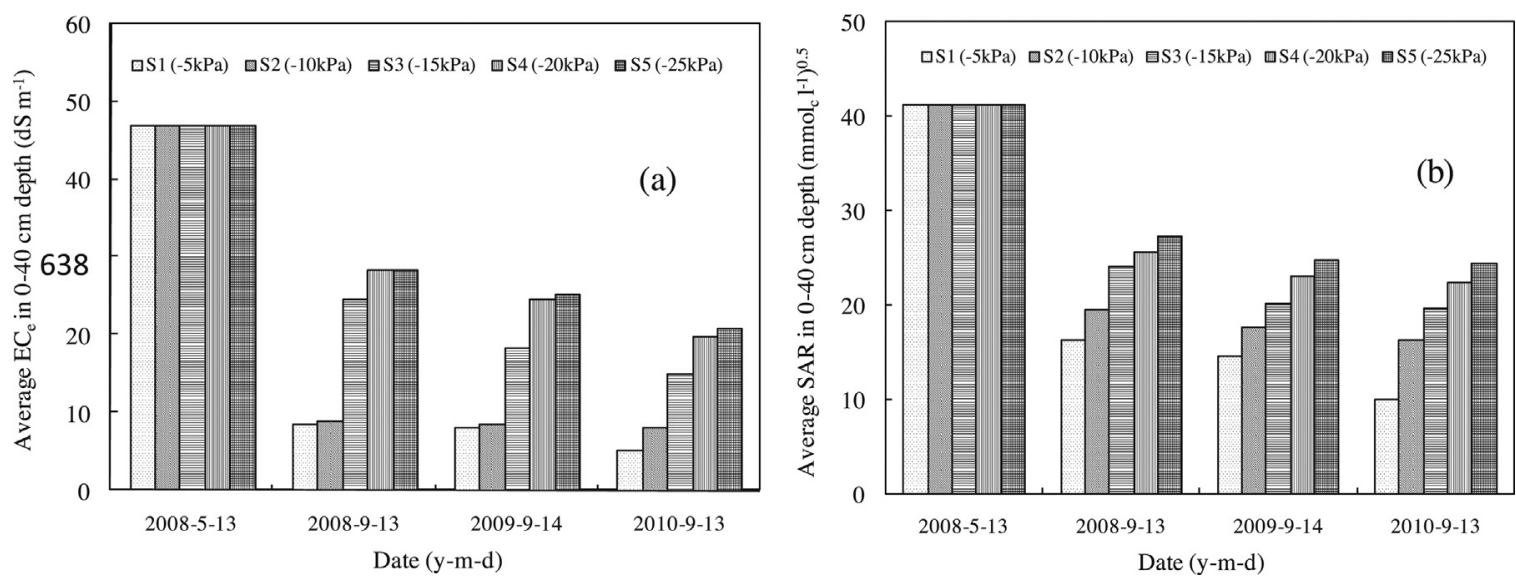

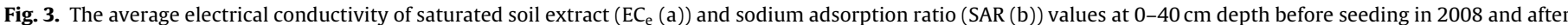

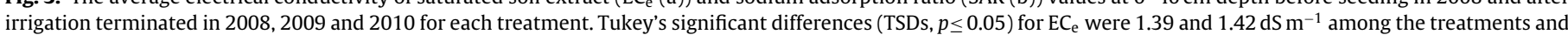
dates, respectively, while for SAR, the TSDs $(p \leq 0.05)$ were 2.89 and 2.92 among the treatments and dates, respectively. 

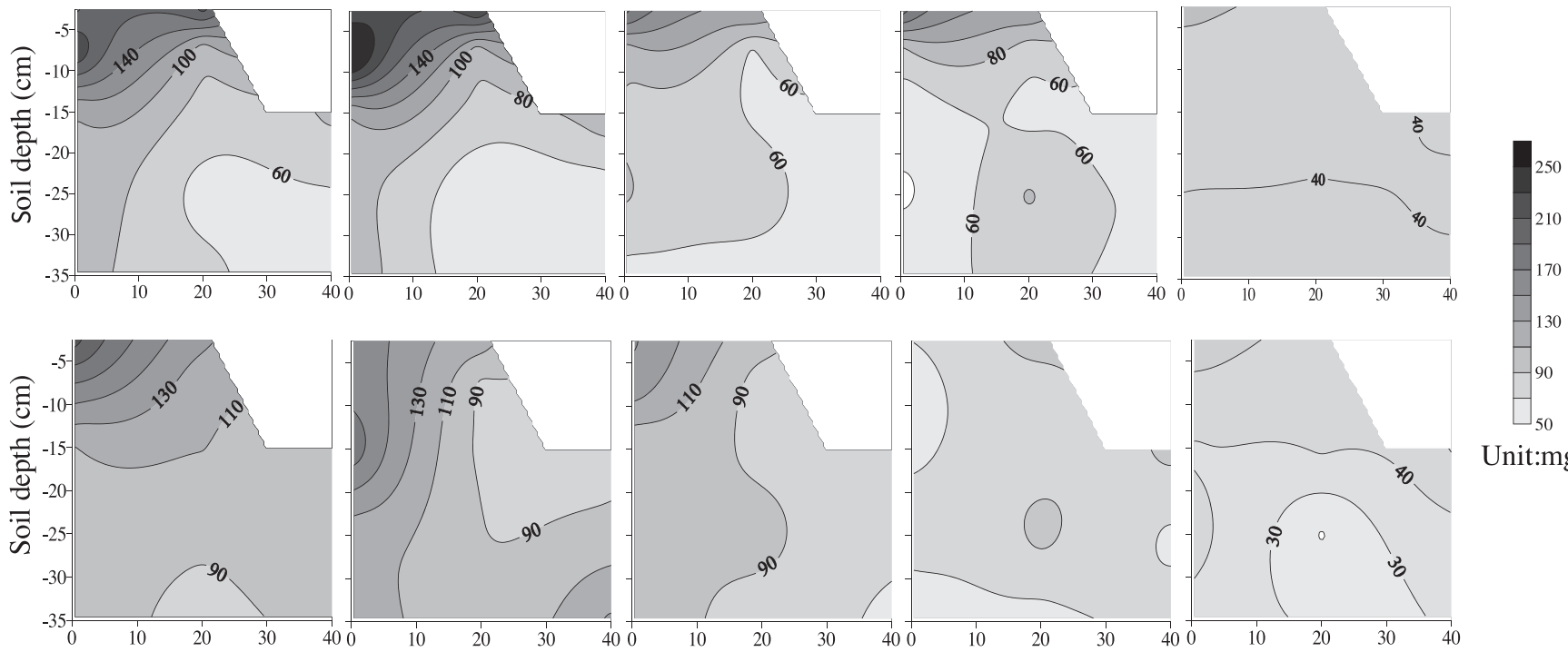

Distance from emitter $(\mathrm{cm})$

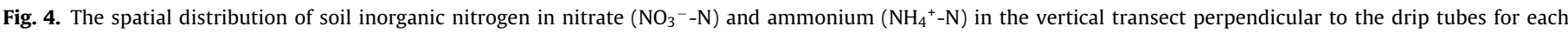
treatment after irrigation ceased in 2010.

Compared with the initial value, the total $\mathrm{N}$ increased by $79.5,69.4$, 43.3, 52.8 and $35.6 \%$ for S1-S5 treatments, respectively, after the experiment ended in 2010. The considerable increase in soil $\mathrm{N}$ was mainly due to the soil reclamation and fertilizer application. During reclamation, both the aboveground and underground parts of the crop can flourish yearly, and large amounts of tiny holes and channels observable in the soil with growing crops indicate a fibrous root system, creating micropores in the soil (Hayashi et al., 2006; Tejada et al., 2006). This can improve hydraulic conductivity in the soil structure and provide available water and nutrients for crops to grow. However, the biologically fixed $\mathrm{N}$ through the crop roots, the shedding of older leaves and the dead plants may also have increased the organic matter and $\mathrm{N}$ content in the upper $40 \mathrm{~cm}$ of soil (Qadir et al., 1997).

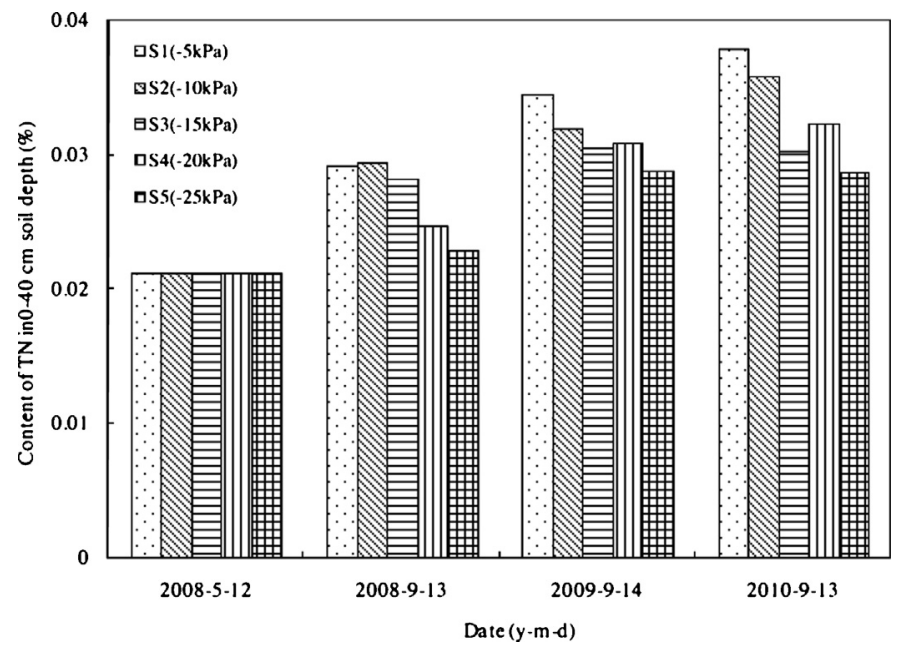

Fig. 5. The total nitrogen (TN) content at $0-40 \mathrm{~cm}$ depth before seeding in 2008 and after irrigation terminated in 2008, 2009 and 2010 for each treatment. The Tukey's significant differences (TSDs) $(p \leq 0.05)$ for TN were 0.0015 and $0.0017 \%$ among the treatments and dates, respectively.

\subsubsection{Soil available $P$}

The soil available P distributions in the soil profile (Fig. 6) were similar to those for soil inorganic N (Fig. 4). By the end of 2010, the average value of soil available $P$ in $0-40 \mathrm{~cm}$ depth had increased to 11.1-6.8 $\mathrm{mg} \mathrm{kg}^{-1}$ for S1-S5 treatment. Most soil available P accumulated in the upper soil layer $(0-20 \mathrm{~cm})$, which might be mainly due to the point-source characteristic of drip irrigation and $\mathrm{P}$ containing fertilizer. In addition, more $\mathrm{CaCO}_{3}$ present at shallower soil depths may have absorbed more $\mathrm{P}$ than in deeper soil layers (Wang et al., 2011, 2012). Soil moisture content influences the effectiveness and availability of applied P (Campo et al., 1998); moreover, the higher water availability in the topsoil under drip irrigation could be related to a higher transformation from organic to available P (Yang et al., 2011). This can explain the phenomenon of available P content in the soil profile being higher in S1 and S2 than in the other treatments (Fig. 6). For S1 and S2 treatments, there was more available P concentrated in deeper soil layers $(30-40 \mathrm{~cm}$ ) under drip emitters than in other treatments. This might be caused by the large amount of applied water, which could leach soil P to deeper layers.

In the cropped treatments, the mineral weathering of apatite, dissolution of slightly soluble $\mathrm{P}$ compounds and mineralization of some organic $\mathrm{P}$ are believed to be the factors responsible for increased soil P content (Qadir et al., 1997; Havlin et al., 2005; Chai et al., 2014). Irrigation method can alter soil properties, thus affecting the transformation and movement of soil nutrients and so affecting soil P content (Yang et al., 2011), which can also explain the changes of soil P content under drip irrigation in the present study.

\subsubsection{Soil available $K$}

After 3 years of the experiment, the soil had available $K$ in the range of $155-179 \mathrm{mg} \mathrm{kg}^{-1}$ in $0-40 \mathrm{~cm}$ depth of soil for the five treatments (Fig. 7). By the end of the experiment, the soil available K had increased by $55.1,36.5,32.5,34.8$ and $45.4 \%$ for S1-S5 treatments, compared with the initial value, respectively. The increase in soil available K was mainly due to the release of K from illite and applied fertilizer. Like many soils in the area, the soil in this study had illite as the dominant clay mineral (Cheng and Fukuhara, 1994; Guan 
$\mathrm{S} 1(-5 \mathrm{kPa})$

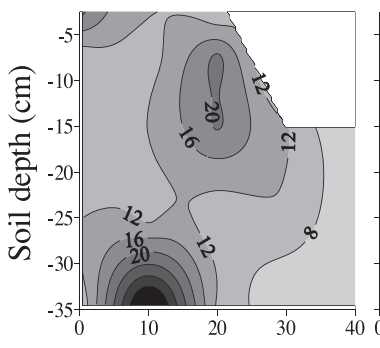

$\mathrm{S} 3(-15 \mathrm{kPa})$

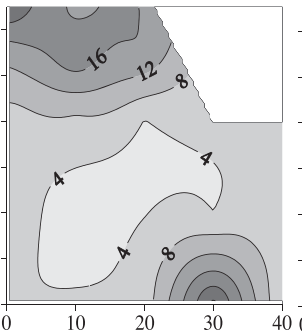

$\mathrm{S} 4(-20 \mathrm{kPa})$

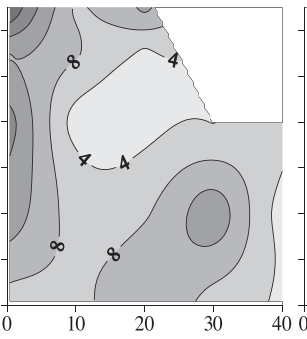

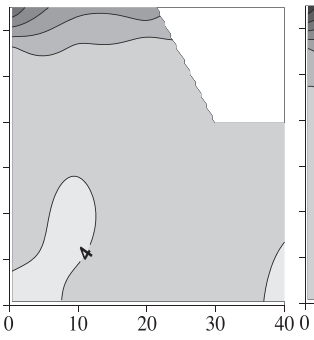

S5 $(-25 \mathrm{kPa})$

Distance from emitter $(\mathrm{cm})$

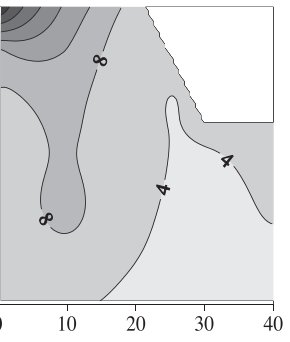

Unit:mg kg-1

Fig. 6. The spatial distribution of available soil P in the vertical transect perpendicular to the drip tubes for each treatment after irrigation ceased in 2010.

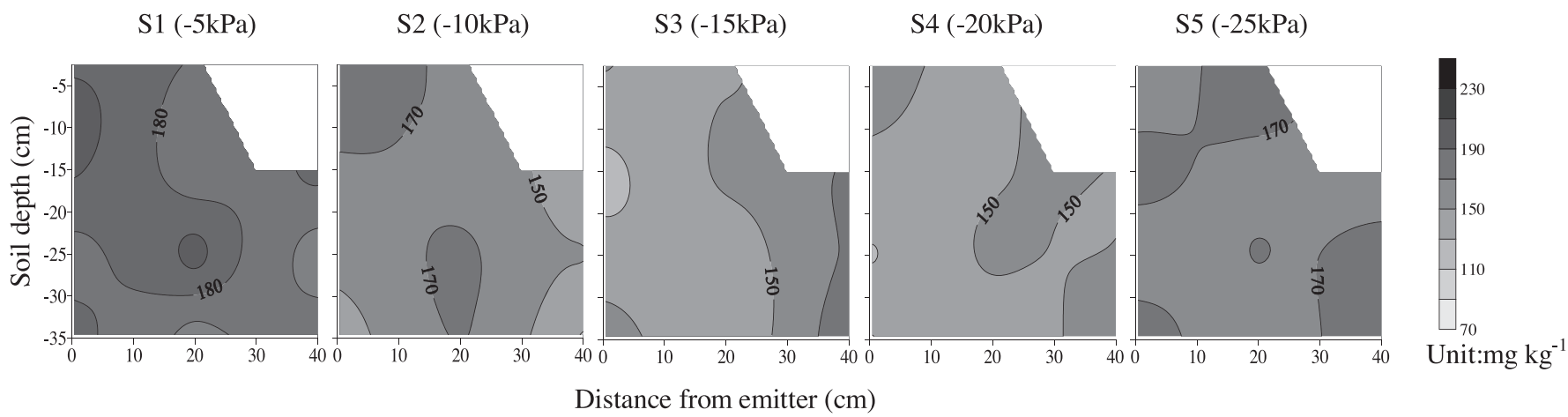

Fig. 7. The spatial distribution of available soil $\mathrm{K}$ in the vertical transect perpendicular to the drip tubes for each treatment after irrigation ceased in 2010 .

et al., 2011), which serves as a good reservoir of plant-available $\mathrm{K}$. The shallower samples had slightly lower concentrations of $\mathrm{K}$, which was similar to those for soil $\mathrm{N}$ and $\mathrm{P}$ (Fig. 7).

\subsubsection{SOC}

In saline-sodic soil, the effects of salinity and sodicity on plant health adversely impact on SOC stocks, generally leading to less SOC (Wong et al., 2010). Comparing with the initial value, there were significant increases in SOC for S1-S3 treatments after the first irrigation season (13 September 2008), and the increase rates from $\mathrm{S} 3$ to $\mathrm{S} 1$ were in the range of $5.3-17.4 \%$ (Fig. 8). For S4

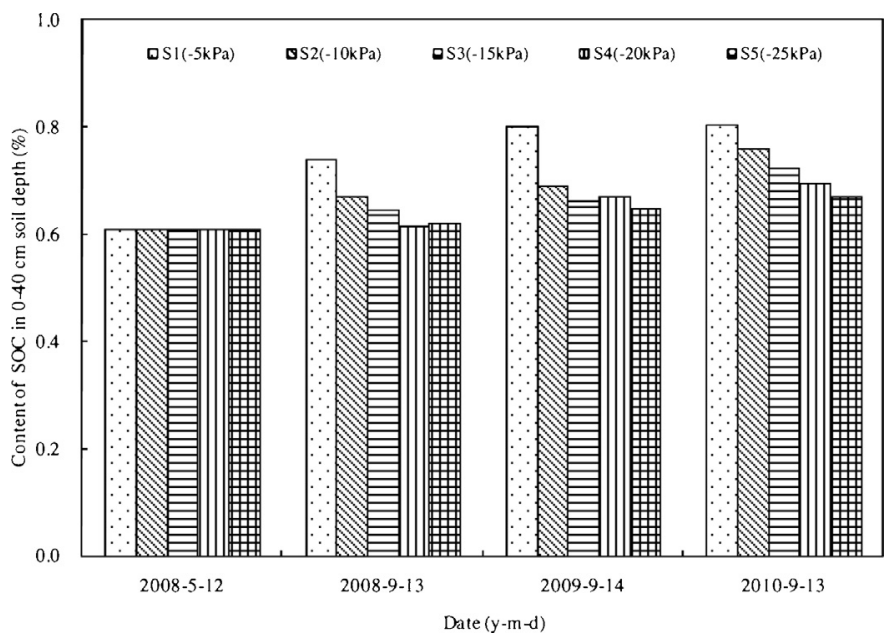

Fig. 8. The content of soil organic carbon (SOC) at $0-40 \mathrm{~cm}$ depth before seeding in 2008 and after irrigation terminated in 2008,2009 and 2010 for each treatment. The Tukey's significant differences (TSDs) $(p \leq 0.05)$ for SOC were 0.03 and $0.05 \%$ among the treatments and dates, respectively. and S5 treatments, the increase rates were not statistically significant. This was mainly due to the more vigorous cotton growth in the S1-S3 than in the other treatments, as soil reclamation was more efficient at higher SMP thresholds (Fig. 3). In the second irrigation season, there was a constant increase in SOC for all treatments, and the highest increase rate of $8.3 \%$ was for the S1 treatment compared with that in the first year (13 September 2008). The presence of plants can increase the SOC in several ways (Jinbo et al., 2006). In the present study, the plant residue after harvest was incorporated into the soil before plowing in the next spring, which was an important factor leading to the consistent increase in SOC each year. Comparing with the initial value, SOC increased by $31.9,24.2,18.5,14.0$ and $9.7 \%$ for S1-S5 treatments, respectively, when the experiment ended in 2010. In highly saline-sodic soils, enhanced SOC loss can occur through dispersion of aggregates on wetting, which increases substrate accessibility and availability to the soil microbial biomass (Oades, 1984). At higher SMP thresholds, soil reclamation was more efficient both for nutrients and for structure, which could explain the differences among the five treatments in SOC each year (Fig. 8).

\subsection{Cotton yield and soil carbon-to-nitrogen (C:N) ratio}

As shown in Table 4, the highest seed cotton yields for both 2009 (2.87 $\mathrm{Mg} \mathrm{ha}^{-1}$ ) and 2010 (3.60 $\mathrm{Mg} \mathrm{ha}^{-1}$ ) were obtained in S1 treatment, for which the yields were 67 and $84 \%$ of the average level for non-saline soil in this region, respectively. Statistical analysis showed that maintaining different SMP values during the growing season had a significant effect on seed cotton yield in both 2009 and 2010. The yields of the five treatments in 2010 were $8-42 \%$ greater than those in 2009. Moreover, the seed cotton yield increased as the SMP thresholds increased, which is in agreement with the results 
Table 4

Seed cotton yield and soil carbon-to-nitrogen (C:N) ratio for each treatment in 2009 and 2010 .

\begin{tabular}{|c|c|c|c|}
\hline Years & Treatment & Seed cotton yield $\left(\mathrm{Mg} \mathrm{ha}^{-1}\right)$ & $C: N$ \\
\hline \multirow[t]{5}{*}{2009} & $\mathrm{~S} 1(-5 \mathrm{kPa})$ & $2.9^{\mathrm{a}}$ & $23.2^{\mathrm{b}}$ \\
\hline & $\mathrm{S} 2(-10 \mathrm{kPa})$ & $2.2^{\mathrm{a}, \mathrm{b}}$ & $23.3^{\mathrm{b}}$ \\
\hline & $\mathrm{S} 3(-15 \mathrm{kPa})$ & $1.9^{\mathrm{a}, \mathrm{b}}$ & $23.7^{\mathrm{a}, \mathrm{b}}$ \\
\hline & $\mathrm{S} 4(-20 \mathrm{kPa})$ & $2.2^{\mathrm{a}, \mathrm{b}}$ & $25.0^{\mathrm{a}, \mathrm{b}}$ \\
\hline & $\mathrm{S} 5(-25 \mathrm{kPa})$ & $1.2^{\mathrm{b}}$ & $27.2^{\mathrm{a}}$ \\
\hline \multirow[t]{5}{*}{2010} & $\mathrm{~S} 1(-5 \mathrm{kPa})$ & $3.6^{\mathrm{a}}$ & $21.5^{\mathrm{c}}$ \\
\hline & $\mathrm{S} 2(-10 \mathrm{kPa})$ & $2.4^{\mathrm{b}}$ & $21.5^{c}$ \\
\hline & $\mathrm{S} 3(-15 \mathrm{kPa})$ & $2.2^{\mathrm{a}, \mathrm{b}}$ & $22.0^{\mathrm{c}}$ \\
\hline & $\mathrm{S} 4(-20 \mathrm{kPa})$ & $2.3^{\mathrm{b}}$ & $22.7^{\mathrm{b}}$ \\
\hline & $\mathrm{S} 5(-25 \mathrm{kPa})$ & $1.8^{\mathrm{c}}$ & $23.6^{\mathrm{a}}$ \\
\hline
\end{tabular}

Values for each separate year in a column followed by the same letter are not significantly different at $p \leq 0.05$.

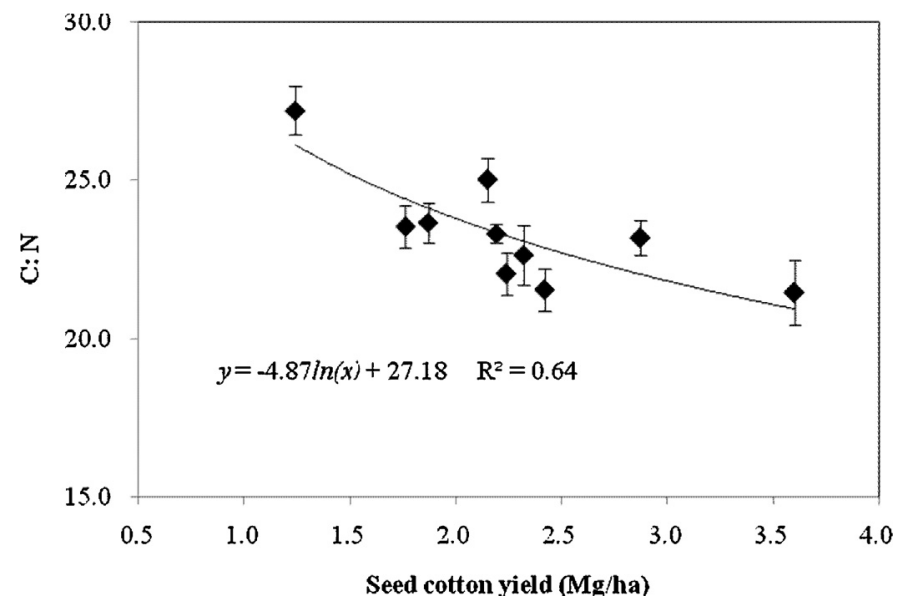

Fig. 9. The relationship between seed cotton yield and soil carbon-to-nitrogen (C:N) ratio for the combined data of 2009 and 2010 .

of a study conducted by Jiao et al. (2006) and Wan et al. (2012) in Ningxia, Northwest China.

Soil carbon-to-nitrogen (C:N) ratio is one of the key factors influencing soil organic matter (SOM) decomposition (Cong et al., 2012). Relatively high C:N ratio (>30) can result in the competition for nitrogen and adverse impact on crop yields (We et al., 2011). In this study, the ratios were significantly influenced by SMP thresholds and were inversely proportional to the SMP thresholds both in 2009 and in 2010 (Table 4). Compared with those in 2009, the ratios in 2010 decreased by 7.4, 7.7, 6.9, 9.4 and $13.4 \%$ for S1, S2, S3, S4 and S5 treatments, respectively.

In crop land, the SOC pool is dependent on inputs from vegetation (Wong et al., 2010). Moreover, soil TN change is generally assumed to follow SOC dynamics because both elements are bound into organic compounds (Cong et al., 2012). In saline-sodic soil, the sum of the osmotic and matric stresses limited crop yields, the amount of applied N, P and $\mathrm{K}$ taken up by the crop and the amount of $\mathrm{C}$ produced by the crop in the form of roots and foliage. Apparently, in regard to the C: $\mathrm{N}$ ratio, the limitation on $\mathrm{N}$ uptake was greater than that on the production of $C$ (Table 4). In high SMP threshold ( $-5 \mathrm{kPa})$ treatment, more soil reclamation occurred, which resulted in vigorous plant growth and more soil microorganism quantity (Batra and Manna, 1997). This can lead to the increasing rates of SOC consumption as well as the soil TN accumulation. Therefore, of all treatments, TN was the highest and SOC was the lowest for the S1 treatment. Consequently, for the combined data of 2009 and 2010, C:N ratio decreased with increasing cotton yield, and a logarithmic function relationship was found between them (Fig. 9).

\section{Conclusions}

The soil salinity, sodicity and nutrients were significantly affected by the SMP thresholds under drip irrigation during the 3 years of reclamation. There were larger reductions of $\mathrm{EC}_{\mathrm{e}}$ and SAR in $\mathrm{S} 1(-5 \mathrm{kPa})$ and $\mathrm{S} 2(-10 \mathrm{kPa})$ than in the other treatments at $0-40 \mathrm{~cm}$ soil depth. The distributions of soil inorganic $\mathrm{N}$ and available $\mathrm{P}$ and $\mathrm{K}$ in the soil profile were mainly influenced by the point-source characteristic of drip irrigation, drip irrigation regime and fertilization mode. With the reclamation in both soil chemical and physical properties, there were dramatic increases in soil $\mathrm{N}, \mathrm{P}$ and K concentration by the end of 3 years of the experiment. The soil concentration of inorganic and total N, available P and K were proportional to the SMP thresholds, as higher SMP resulted in more efficient soil reclamation. Since cotton growth became more vigorous during reclamation, there was also a considerable increase (9.7-31.9\%) in SOC by the end of 2010, and the increased rates were proportional to SMP thresholds. The highest cotton yield was obtained in S1 ( $-5 \mathrm{kPa})$ treatment for both $2009\left(2.87 \mathrm{Mg} \mathrm{ha}^{-1}\right)$ and 2010 (3.60 $\mathrm{Mg} \mathrm{ha}^{-1}$ ). The soil C: $\mathrm{N}$ ratios were inversely proportional to the SMP thresholds in 2009 and 2010. Overall, considering the soil reclamation efficiency, soil nutrient stocks and cotton yield, SMP thresholds of -5 and $-10 \mathrm{kPa}$ could be used as effective measures to trigger irrigation in the first 3 years of saline-sodic soil reclamation in Xinjiang, Northwest China.

\section{Acknowledgment}

This study was supported by the Fundamental Research Funds for the Central Universities (BLX2012042), the National Natural Science Fund (31300530), the National High-Tech R\&D Program of China (2011AA100507), the Action Plan for the Development of Western China of the Chinese Academy of Sciences (KZCX2-XB316) and the National Science Foundation for Young Scientists of China (51009126).

\section{References}

Al-Karaki, G.N., 1997. Barley response to salt stress at varied levels of phosphorus. J. Plant Nutr. 20, 1635-1643.

Bao, S.D., 2005. Soil Analysis in Agricultural Chemistry (in Chinese). China Agricultural Press, Beijing.

Batra, L., Manna, M.C., 1997. Dehydrogenase activity and microbial biomass carbon in salt-affected soils of semiarid and arid regions. Arid Land Res. Manage. 11, 295-303.

Bundy, L.G., Meisinger, J.J., 1994. Nitrogen availability indices. In: Weaver, R.W., Angle, J.S., Bottomley, P.S. (Eds.), Methods of Soil Analysis: Microbiological and Biochemical Properties. Part 2. Soil Science Society of America Inc. American Society of Agronomy, Inc., Madison, Wisconsin, USA, pp. 951-984.

Campo, J., Jaramillo, V.J., Maass, J.M., 1998. Pulses of soil phosphorus availability in a Mexican tropical dry forest: effects of seasonality and level of wetting. Oecologia $115,167-172$

Chai, F.M., Yang, F.Q., Li, Q., Zang, M., Geng, X.X., Meng, Q.P., 2014. Metallogenic mechanism of the Abagong apatite-rich iron deposit in Altay, Xinjiang: evidence from inclusions and stable isotopes. Acta Petrol. Sin. 30 (5), 1397-1414 (in Chinese with English abstract).

Chen, M., Kang, Y.H., Wan, S.Q., Liu, S.P., 2009. Drip irrigation with saline water for oleic sunflower (Helianthus annuus L). Agric. Water Manage. 96, 1766-1772.

Chen, W., Hou, Z., Wu, L., Liang, Y., Wei, C., 2010. Evaluating salinity distribution in soil irrigated with saline water in arid regions of northwest China. Agric. Water Manage. 97, 2001-2008.

Cheng, X., Fukuhara, M., 1994. The preliminary study on soil classification in arid area of Xinjiang using Landsat data. Arid Zone Res. 11 (2), 1-6 (in Chinese with English abstract).

Cong, R.H., Wang, X.J., Xu, M.G., Zhang, W.J., Xie, L.J., Yang, X.Y., Huang, S.M., Wang, B.R., 2012. Dynamics of soil carbon to nitrogen ratio changes under long-term fertilizer addition in wheat-corn double cropping systems of China. Eur. J. Soil Sci. 63, 341-350.

Dou, C.Y., Kang, Y.H., Wan, S.Q., Hu, W., 2011. Soil salinity changes under cropped with Lycium barbarum L. and irrigated with saline-sodic water. Pedosphere 21 (4), 539-548.

Elgharably, A., 2011. Wheat response to combined application of nitrogen and phosphorus in a saline sandy loam soil. Soil Sci. Plant Nutr. 57 (3), 396-402. 
Guan, X., Li, Q., Zhang, F., 2011. Comparison of soil genetic classification and soil taxonomy for plain soil in Xinjiang. J. Hunan Agric. Univ. (Nat. Sci.) 37 (3), 312-317 (in Chinese with English abstract).

Hanson, B.R., Hutmacher, R.B., May, D.M., 2006. Drip irrigation of tomato and cotton under shallow saline ground water conditions. Irrig. Drain. Syst. 20, 155-175.

Havlin, J.L., Tisdale, S.L., Nelson, W.L., Beaton, J.D., 2005. Soil Fertility and Fertilizers: An Introduction to Nutrients Management, seventh ed. Prentice Hall, New York.

Hayashi, Y., Kenichirou, K., Mizuyama, T., 2006. Changes in pore size distribution and hydraulic properties of forest soil resulting from structural development. J. Hydrol. 331 (30), 85-102.

Hu, X., Chen, H., Wang, J., Meng, X., Chen, F., 2009. Effects of soil water content on cotton root growth and distribution under mulched drip irrigation. Agric. Sci. China 8 (6), 709-716.

Jiao, Y.P., Kang, Y.H., Wan, S.Q., Liu, W.,2006. Effect of soil matric potential on waxy corn (Zea mays L. sinensis Kulesh) growth and water use under drip irrigation in saline soils of arid areas. In: The Proceedings of the 8th International Dryland Development Conference. Beijing.

Jinbo, Z., Changchun, S., Wenyan, Y., 2006. Land use effects on the distribution of labile organic carbon fractions through soil profiles. Soil Sci. Soc. Am. J. 70, 660-667.

Keller, J., Bliesner, R.D. (Eds.), 1990. Sprinkle and Trickle Irrigation. Van Nostrand Reinhold, New York, p. 22.

Ma, C., Naidu, R., Liu, F., Lin, C., Ming, H., 2012. Influence of hybrid giant Napier grass on salt and nutrient distributions with depth in a saline soil. Biodegradation 23, 907-916.

Maas, E.V., Hoffman, G.J., 1977. Crop salt tolerance-current assessment. J. Irrig. Drain. Div. 103 (IR2), 115.

Oades, J.M., 1984. Soil organic matter and structural stability: mechanisms and implications for management. Plant Soil 76, 319-337.

Olsen, S.R., Sommers, L.E., 1982. Phosphorus. In: Page, A.L., Miller, R.H., Keeney, D.R. (Eds.), Methods of Soil Analyses: Part 2. Chemical and Microbiological Properties. American Society of Agronomy, Madison, Wisconsin, pp. 403-430.

Oster, J.D., Shainberg, I., Abrol, I.P., 1996. Reclamation of salt-affected soil. In: Agassi, M. (Ed.), Soil Erosion, Conservation and Rehabilitation. Marcel Dekker, New York, pp. 315-352.

Qadir, M., Oster, J.D., Schubert, S., Noble, A.D., Sahrawat, K.L., 2007. Phytoremediation of sodic and saline-sodic soils. Adv. Agron. 96, 197-247.

Qadir, M., Qureshi, R.H., Ahmad, N., 1997. Nutrient availability in a calcareous saline-sodic soil during vegetative bioremediation. Arid Soil Res. Rehabil. 11 (4), 343-352.

Qadir, M., Qureshi, R.H., Ahmad, N., 2002. Amelioration of calcareous saline-sodic soils through phytoremediation and chemical strategies. Soil Use Manage. 18, 381-385.
Robbins, C.W., 1986a. Sodic calcareous soil reclamation as affected by different amendments and crops. Agron. J. 78, 916-920.

Robbins, C.W., 1986b. Carbon dioxide partial pressure in lysimeter soils. Agron. J. 78, $151-158$.

Stuart, N.W., 1936. Adaption of the micro-Kjeldahl method for the determination of nitrogen in plant tissues. Plant Physiol. 11, 173-179.

Sun, J., Kang, Y.H., Wan, S., Hu, W., Jiang, S., Zhang, T., 2012. Soil salinity management with drip irrigation and its effects on soil hydraulic properties in north China coastal saline soils. Agric. Water Manage. 115, 10-19.

Tejada, M., Garcia, C., Gonzalez, J.L., Hernandez, M.T., 2006. Use of organic amendment as a strategy for saline soil remediation: influence on the physical, chemical and biological properties of soil. Soil Biol. Biochem. 38, 1413-1421.

Wan, S., Jiao, Y., Kang, Y.H., 2012. Drip irrigation for waxy corn (Zea mays L. var ceratina Kulesh) production in very strongly saline conditions. Agric. Water Manage. 104, 210-220.

Wang, R., Kang, Y.H., Wan, S., Hu, W., Liu, S., Liu, S., 2011. Salt distribution and the growth of cotton under different drip irrigation regimes in a saline area. Agric Water Manage. 100, 58-69.

Wang, R., Kang, Y.H., Wan, S., Hu, W., Liu, S., Jiang, S., Liu, S., 2012. Influence of different amounts of irrigation water on salt leaching and cotton growth under drip irrigation in an arid and saline area. Agric. Water Manage. 110 109-117.

Wang, X., Tian, C., Wen, Q., 2007. Influence of land utilization way on soil salt in Karamay Agricultural Development Zones. J. Xinjiang Agric. Univ. 30 (2), 38-40 (in Chinese with English abstract).

Wang, Z.Q., Zhu, S.Q., Yu, R., 1993. Salt-affected Soils of China. Science Press, Beijing, pp. 276 (in Chinese).

We, H., Guihua, L., Yi, R., Changbao, M., Shuxiang, Z., 2011. The effects of combined organic manure in different carbon-to-nitrogen ratio on wheat biomass and soil fertility in low fertility soil. Soil Fertil. Sci. China 2,22-27 (in Chinese with English abstract).

Wong, V.N.L., Murphy, B.W., Koen, T.B., Greene, R.S.B., Dalal, R.C., 2008. Soil organic carbon stocks in saline and sodic landscapes. Aust. J. Soil Res. 46, 378-389.

Wong, V.N.L., Greene, R.S.B., Dalal, R.C., Murphy, B.W., 2010. Soil carbon dynamics in saline and sodic soils: a review. Soil Use Manage. 26, 2-11.

Xi, J., Zhang, F., Mao, D., 2005. Saline-soil distribution and halophyte resources in Xinjiang. Chin. J. Soil Sci. 36 (3), 299-303 (in Chinese with English abstract).

Yang, L.J., Zhang, Y.L., Li, F.S., Lemcoff, J.H., 2011. Soil phosphorus distribution as affected by irrigation methods in plastic film house. Pedosphere 21 (6), 712-718.

Yin, F., Fu, B., Mao, R., 2007. Effects of nitrogen fertilizer application rates on nitrate nitrogen distribution in saline soil in the Hai River Basin, China. J. Soils Sedim. 7 (3), 136-142. 